\title{
Third Nerve Palsy: Analysis of 1400 Personally-examined Inpatients
}

\author{
James R. Keane
}

\begin{abstract}
Background: Most studies of third nerve palsy (TNP) antedate computerized imaging and focus primarily on chart review of referral outpatients. Methods: To compare a large contrasting population, I reviewed 1400 personally-examined municipal hospital inpatients with TNPs seen over 37 years. Results: TNPs were bilateral in 11\%, complete in 33\%, without other neurological signs (isolated) in $36 \%$, and associated with recurrent cranial neuropathies in $7 \%$. Third nerve damage occurred in the subarachnoid space in $32 \%$, the cavernous sinus in $23 \%$, the brainstem in $14 \%$, as a nonlocalized peripheral neuropathy in $18 \%$ and at an uncertain location in $13 \%$. Causes were trauma $(26 \%)$, tumor $(12 \%)$, diabetes $(11 \%)$, aneurysm $(10 \%)$, surgery $(10 \%)$, stroke $(8 \%)$, infection (5\%), Guillain-Barre and Fisher syndromes (5\%), idiopathic cavernous sinusitis (3\%), benign self-limited (2\%), miscellaneous (4\%), and unknown (3\%). Local causes, besides an abundance of trauma, included six cases involving cysticercosis, four with wound botulism, and one with coccidiomycotic meningitis. Of 234 patients with diabetes, microvascular ischemia was the cause of TNP in only two-thirds (five had aneurysms) and $53 \%$ of those with diabetic microvascular ischemia had pupillary involvement-often bilateral, suggesting concomitant autonomic neuropathy. Only $2 \%$ of aneurysms spared the pupil. A painful onset occurred with $94 \%$ of aneurysm and $69 \%$ of diabetic cases. Conclusions: Bilateral TNPs, multiple cranial neuropathies, and accompanying neurological signs were common among our inpatients, as were causes rare in outpatient settings such as severe trauma, transtentorial herniation, midbrain strokes, and the Guillain-Barre syndrome. Few cases remained undiagnosed and nondiabetic ischemia was rare.
\end{abstract}

RÉSUMÉ: Paralysie du troisième nerf : analyse de 1400 patients hospitalisés examinés par le même observateur. Contexte : La plupart des études sur la paralysie du troisième nerf (PTN) sont antérieures à la tomodensitométrie et sont constituées principalement de revues de dossiers de patients externes. Méthodes : Afin d'examiner un volet différent de la PTN, j'ai révisé 1400 dossiers de patients atteints d'une PTN, hospitalisés dans un hôpital municipal, que j'ai moi-même examinés au cours d'une période de 37 ans. Résultats : La PTN était bilatérale chez $11 \%$ des patients, complète chez $33 \%$, sans autre signe neurologique (isolée) chez $36 \%$ et associée à des neuropathies crâniennes récurrentes chez $7 \%$. La lésion du troisième nerf était située dans l'espace sous-arachnoïdien chez 32\%, dans le sinus caverneux chez 23\%, dans le tronc cérébral chez 14\%, comme une neuropathie périphérique non localisée chez $18 \%$ et à un endroit indéterminé chez 13\%. Les causes étaient un traumatisme chez 26\%, une tumeur chez 12\%, un diabète chez $11 \%$, un anévrisme chez $10 \%$, une chirurgie chez $10 \%$, un accident vasculaire cérébral chez $8 \%$, une infection chez $5 \%$, un syndrome de Guillain-Barré ou de Fisher chez 5\%, une sinusite caverneuse idiopathique chez 3\%, une cause autolimitée bénigne chez $2 \%$, des causes variées chez $4 \%$ et des causes inconnues chez 3\%. Les causes locales, excluant les nombreux cas de traumatisme, comprenaient 6 cas de cysticercose, 4 de botulisme relié à une plaie et 1 cas de méningite à coccidiomycose. L'ischémie microvasculaire était la cause de la PTN chez seulement les deux tiers des 234 patients diabétiques dont 5 étaient porteurs d'anévrismes et $53 \%$ avaient une atteinte pupillaire, souvent bilatérale, ce qui est compatible avec la présence d'une neuropathie autonomique. La pupille n'était pas atteinte chez seulement $2 \%$ des patients porteurs d'anévrismes. Le début avait été douloureux chez $94 \%$ des patients porteurs d'anévrismes et $69 \%$ des diabétiques. Conclusions : La PTN bilatérale, les neuropathies crâniennes multiples et les signes neurologiques associés sont fréquents chez nos patients hospitalisés, de même que les étiologies qui sont rares chez les patients externes comme les traumatismes sévères, la hernie transtentorielle, les accidents vasculaires cérébraux et le syndrome de Guillain-Barré. Un diagnostic n’a pu être posé dans un très petit nombre de cas et l'ischémie non diabétique était rare.

Can. J. Neurol. Sci. 2010; 37: 662-670

Third nerve palsy (TNP) may be difficult to diagnose, the causes are often elusive, the prognosis is potentially catastrophic, and the optimal workup is currently in flux. The landmark large study of TNP is composed of four sequential articles on ocular motor nerve palsies, each describing ten years experience at the Mayo Clinic ${ }^{1-4}$. That survey and most other studies of TNP ${ }^{5-11}$ (Table 1) are based largely upon referral patients seen by many different doctors with only several having even a token experience with magnetic resonance imaging (MRI). The present study explores the causes and sites of TNP in a large contrasting group of municipal hospital inpatients examined by a single neuro-ophthalmologist.

\section{METHODS}

Inpatients personally-examined on wards of the Los Angeles County/University of Southern California Medical Center and

From the University of Southern California Medical School, Los Angeles, California, USA.

Received July 9, 2009. Final Revisions Submitted March 4, 2010. Correspondence to: James R. Keane, 6281 Vine Way, Los Angeles, California, 90068 , USA. 
Table 1: Causes and locations of third nerve palsy: present study

\begin{tabular}{|c|c|c|c|c|c|c|c|c|c|}
\hline \multicolumn{5}{|c|}{ CAUSE number of cases $(\%)$} & \multicolumn{5}{|c|}{ LOCATION number of cases } \\
\hline Cause & $\begin{array}{c}\text { Total } \\
N=1400\end{array}$ & $\begin{array}{l}\text { Isolated } \\
\mathbf{N}=\mathbf{5 0 0}\end{array}$ & $\begin{array}{l}\text { Unilateral } \\
\mathrm{N}=1250\end{array}$ & $\begin{array}{l}\text { Bilateral } \\
N=150\end{array}$ & $\begin{array}{l}\text { Cavernous } \\
\text { sinus } \\
\mathrm{N}=\mathbf{3 2 0}\end{array}$ & $\begin{array}{l}\text { Subarachnoid } \\
\text { Space } \\
\mathrm{N}=449\end{array}$ & $\begin{array}{l}\text { Brainstem } \\
\mathbf{N}=197\end{array}$ & $\begin{array}{l}\text { Peripheral } \\
\text { nerve } \\
N=256\end{array}$ & $\begin{array}{l}\text { Unknown } \\
\mathrm{N}=178\end{array}$ \\
\hline TRAUMA & $369 \quad(26)$ & $107 \quad(21)$ & 354 & 15 & 97 & 112 & 27 & $\mathbf{0}$ & 133 \\
\hline TUMOR & $173 \quad(12)$ & $11 \quad(2)$ & 154 & 19 & 112 & 42 & 18 & $\mathbf{0}$ & 1 \\
\hline DIABETES & $156 \quad(11)$ & 151 & 152 & 4 & $\mathbf{0}$ & $\mathbf{0}$ & $\mathbf{0}$ & 156 & $\mathbf{0}$ \\
\hline ANEURYSM & $145 \quad(10)$ & $101 \quad(20)$ & 144 & 1 & 8 & 134 & 3 & $\mathbf{0}$ & $\mathbf{0}$ \\
\hline SURGERY & $140 \quad(10)$ & $40 \quad(8)$ & 134 & 6 & 38 & 79 & 23 & $\mathbf{0}$ & $\mathbf{0}$ \\
\hline STROKE & $114 \quad(8)$ & $2(0.4)$ & 87 & 27 & $\mathbf{0}$ & 15 & 99 & $\mathbf{0}$ & $\mathbf{0}$ \\
\hline INFECTION & $65 \quad(5)$ & $\begin{array}{ll}9 & (2)\end{array}$ & 46 & 19 & 10 & 32 & 15 & 3 & 5 \\
\hline G-B syndrome & $38 \quad(3)$ & $\begin{array}{ll}0 & (0) \\
\end{array}$ & 8 & 30 & $\mathbf{0}$ & $\mathbf{0}$ & $\mathbf{0}$ & 38 & $\mathbf{0}$ \\
\hline $\begin{array}{l}\text { FISHER } \\
\text { syndrome }\end{array}$ & $24 \quad(2)$ & $\begin{array}{ll}0 & \text { (0) }\end{array}$ & 2 & 22 & $\mathbf{0}$ & $\mathbf{0}$ & $\mathbf{0}$ & 24 & $\mathbf{0}$ \\
\hline ICS & $\begin{array}{ll}49 & (3) \\
\end{array}$ & $10 \quad(2)$ & 49 & $\mathbf{0}$ & 49 & $\mathbf{0}$ & $\mathbf{0}$ & $\mathbf{0}$ & $\mathbf{0}$ \\
\hline BENIGN & $27 \quad(2)$ & $22 \quad$ (4) & 27 & $\mathbf{0}$ & $\mathbf{0}$ & $\mathbf{0}$ & $\mathbf{0}$ & 27 & $\mathbf{0}$ \\
\hline OTHER & $63 \quad(4)$ & $17 \quad(3)$ & 56 & 7 & 4 & 35 & 11 & 8 & 5 \\
\hline UNKNOWN & $37 \quad$ (3) & \begin{tabular}{|ll}
30 & $(6)$ \\
\end{tabular} & 37 & $\mathbf{0}$ & 2 & $\mathbf{0}$ & 1 & $\mathbf{0}$ & 34 \\
\hline$($ HERNIATION) $\Delta$ & [186] & [19] & {$[176]$} & [9] & {$[0]$} & [159] & [27] & {$[0]$} & {$[0]$} \\
\hline (RECURRENT) $\Delta$ & [92] & [65] & [87] & [6] & [22] & {$[7]$} & [3] & [59] & [2] \\
\hline
\end{tabular}

ICS=idiopathic cavernous sinusitis, isolated=without other neurological signs; $\Delta$ Cases of transtentorial herniation and recurrent cranial neuropathies are tallied under primary causes

Rancho Los Amigos National Rehabilitation Center of Downey, California, from 1971 through 2007 were studied. The Medical Center, a large municipal hospital serving an urban population with many recent immigrants, shares patients with other local municipal hospitals and clinics, ethnic healers and pharmacies, and medical facilities in Mexico. (Each year nearly one million residents of Los Angeles seek medical care in $\mathrm{Mexico}^{12}$.) As advanced disease is common and follow-up limited, most patients with TNP are evaluated as inpatients.

The present study is based upon my notes of all patients and photographs of many (slides of 555 patients, super 8 film clips of

Table 2: Cranial neuropathies accompanying third nerve palsy

\begin{tabular}{crl}
\hline Cranial nerve number & \#Nerves $(\%) \quad \mathrm{N}=1095$ \\
2 & 158 & $(14)$ \\
4 & 138 & $(13)$ \\
5 & 155 & $(14)$ \\
6 & 336 & $(31)$ \\
7 & 184 & $(17)$ \\
8 & 27 & $(2)$ \\
10 & 53 & $(5)$ \\
11 & 15 & $(1)$ \\
12 & 29 & $(3)$ \\
\hline
\end{tabular}

31 , and videotapes of 54 were available), as well as selected hospital charts and postmortem reports of 52 patients. Diagnosis and location were determined by history and examination, supported by laboratory studies, testing for myasthenia, cerebrospinal fluid examination, and generous use of contemporary radiological contrast studies and computerized scans, as clinically indicated. About 100 patients antedated computed tomogram (CT) scanning and 650 preceded use of MRI at our hospital.

Involvement of two or more elements of the third nerve (TN) was required for inclusion and maximum observed severity was used for comparison. Only the immediate neuropathy of serial TNPs was tallied. Comatose patients lacking spontaneous eye movements were excluded. When multiple causes or locations applied, the single most important one was selected. A "benign" diagnosis was applied to self-limited TNPs in patients under age 50 if extensive testing revealed no other cause. Botulism was included but myasthenia was not.

\section{RESULTS}

Of 1400 patients, $792(57 \%)$ were male and ages ranged from 3 to 89 years with a mean of 42 . The right side was involved in $654(47 \%)$, the left in $596(43 \%)$, and both sides in 150 patients $(11 \%)$, giving a total of 1550 impaired third nerves (TNs). The subarachnoid space was the site of involvement in $32 \%$ of cases, the cavernous sinus in $23 \%$, the brainstem in $14 \%$, a nonlocalized neuropathy in $18 \%$, and location was uncertain in $13 \%$ (Table 1).

Third nerve palsy was the sole neurological sign (isolated) in 500 cases ( $40 \%$ of unilateral cases and $4 \%$ of bilateral cases) 
Table 3: Prior cranial neuropathies in patients with third nerve palsy

\begin{tabular}{|c|c|c|c|c|c|c|c|c|c|c|c|}
\hline \multirow{2}{*}{$\begin{array}{l}\text { Cranial } \\
\text { Nerve }\end{array}$} & \multicolumn{11}{|c|}{ Number Of Cranial Neuropathies } \\
\hline & $\begin{array}{l}\text { Diabetes } \\
\mathrm{N}=\mathbf{4 1}\end{array}$ & $\begin{array}{l}\text { Benign } \\
\mathrm{N}=16\end{array}$ & $\begin{array}{l}\text { ICS } \\
N=16\end{array}$ & $\begin{array}{l}\text { Infection } \\
\mathbf{N}=\mathbf{2}\end{array}$ & $\begin{array}{l}\text { Tumor } \\
\mathrm{N}=5\end{array}$ & $\begin{array}{l}\text { Aneurysm } \\
\mathbf{N}=\mathbf{4}\end{array}$ & $\begin{array}{l}\text { Vasculitis } \\
\mathbf{N}=\mathbf{2}\end{array}$ & $\begin{array}{l}\text { G-B-F } \\
\mathrm{N}=2\end{array}$ & $\begin{array}{l}\text { Ophthalmic } \\
\text { Migraine } \\
\mathrm{N}=2\end{array}$ & $\begin{array}{l}\text { Other } \\
* * \\
\mathbf{N}=\mathbf{3}\end{array}$ & $\begin{array}{l}\text { Total } \\
\mathbf{N}=93\end{array}$ \\
\hline 2 & 0 & 0 & $\mathbf{0}$ & & 1 & 1 & & & & & 2 \\
\hline 3 & 14 & 4 & 4 & & 2 & 2 & & & 10 & 1 & 37 \\
\hline 4 & 1 & (1) & $\mathbf{0}$ & & & & & & & & 1 \\
\hline 5 & 0 & 1 & 1 & & & & 1 & & & & 3 \\
\hline 6 & 11 & 10 & 10 & 3 & 1 & 1 & 0 & & & 1 & 37 \\
\hline 7 & 30 & 2 & 2 & & 1 & & 2 & 2 & & 3 & 42 \\
\hline 8 & 0 & ( & 0 & & 1 & & 1 & & & 1 & 3 \\
\hline 10 & (0) & 0 & 0 & & & & & & & & $\mathbf{0}$ \\
\hline 11 & 0 & 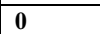 & 0 & & & & & & & & 0 \\
\hline 12 & 0 & (1) & $\mathbf{0}$ & & & & & & & & $\mathbf{0}$ \\
\hline TOTAL & 56 & 17 & 17 & 3 & 6 & 4 & 4 & 2 & 10 & 6 & 125 \\
\hline
\end{tabular}

$\mathrm{N}=$ Number of patients, $*$ cysticercosis, syphilis; **trauma, benign intracranial hypertension, unknown

(Table 1) Isolated cases occurred most commonly with diabetic TNP $(97 \%)$, benign cases $(81 \%)$, unknown causes $(81 \%)$, and aneurysms $(70 \%)$, and least commonly with the Guillain-Barre (G-B) and Fisher (F) syndromes (0), strokes (2\%), other (3\%), and tumor $(6 \%)$ (Table 1$)$. The TN was the only cranial nerve affected in 843 patients $(60 \%)$. In the 557 patients with 1095 concomitant neuropathies of other cranial nerves, sixth nerve palsies were common; seventh, second, fifth, and fourth neuropathies occurred frequently; and tenth, twelfth, eighth, and eleventh nerve palsies were rarely seen (the first and ninth nerves were not tallied) (Table 2).

Recurrent cranial neuropathy was a feature of 93 patients with 125 prior neuropathies. Nearly one-half of recurrences involved diabetic TNPs (41 cases, 56 nerves), and a majority of the remaining cases were divided between idiopathic cavernous sinusitis (ICS) and benign causes (Table 3). Most patients (66) had two episodes of resolving cranial neuropathy, but 21 had three, six had four, and one patient with ophthalmoplegic migraine syndrome had six episodes. In ten cases (five tumor, three aneurysm, and one each G-B and F syndromes) prior neuropathies were unrelated to the current TNP and most often were due to Bell's palsy (four cases) or old head trauma (two cases).

Despite limited follow-up, signs of aberrant regeneration of the TN were noted in 95 patients. Most cases were due to trauma $(65 \%)$, with aneurysms $(13 \%)$, tumors $(8 \%)$ and surgery $(8 \%)$ comprising most of the remaining cases (Table 4). A superior division TNP was seen in 20 cases, with three each due to surgery, diabetes and trauma (two herniation), two each aneurysm and benign causes, and other causes seven. A single patient had an inferior division palsy, following trauma.

Associated neuro-ophthalmological findings included nystagmus in $7 \%$, homonymous hemianopia in $7 \%$, gaze pareses in $4 \%$, papilledema in $3 \%$, and internuclear ophthalmoplegia in $1 \%$.
The pupil was fixed in $40 \%$, either fixed or minimally responsive (fixed to the casual examiner) in 54\%, moderately reactive in $17 \%$, normally reactive in $24 \%$ (normally reactive and equal [spared] in 14\%), and reactivity was obscured by iatrogenic dilatation or surgery in $5 \%$ (Table 5).

The pupil on the side of the TNP was $\geq 0.5 \mathrm{~mm}$ smaller in 45 cases (3\% of unilateral cases). None of these patients showed evidence of TN aberrant regeneration, but six had Horners syndrome. The light reaction was impaired in 23 patients (bilaterally in nine). Miosis occurred with all locations and most causes but was singularly common $(15 \%)$ in idiopathic cavernous sinusitis cases (Table 5).

An oval pupil, found in 49 cases (55 eyes), also was present in all locations and most causes but was singularly common (17\%) in Fisher's syndrome (Table 5). There was no overlap of miotic and oval pupils.

The pupil in 117 TNPs caused by pcom aneurysms was reactive in $37 \%$ but normal in just $1 \%$ (the case with superior division palsy excepted) (Table 5). The pupil was abnormal in

Table 4: Causes of third nerve palsy with aberrent regeneration

\begin{tabular}{c|c|c|c}
\hline Cause & $\begin{array}{c}\text { \# patients } \\
\mathbf{N}=95\end{array}$ & $\begin{array}{c}\% \text { with } \\
\text { same } \\
\text { diagnosis }\end{array}$ & $\begin{array}{c}\% \text { of aberrant } \\
\text { regeneration } \\
\text { cases }\end{array}$ \\
\hline TRAUMA & 62 & 17 & 65 \\
\hline ANEURYSM & 12 & 8 & 13 \\
\hline TUMOR & $\mathbf{8}$ & 5 & $\mathbf{8}$ \\
\hline SURGERY & $\mathbf{8}$ & $\mathbf{6}$ & $\mathbf{8}$ \\
\hline OTHER & 5 & 1 & 5 \\
CAUSES & & &
\end{tabular}


Table 5: Pupil findings vs. cause and location of third nerve palsy Patients (\%)

\begin{tabular}{|c|c|c|c|c|c|c|}
\hline ETIOLOGY & $\begin{array}{l}\text { FIXED } \\
\text { PUPIL }\end{array}$ & $\begin{array}{l}\text { FIXED \& } \\
\text { MINIMALLY } \\
\text { REACTIVE } \\
\end{array}$ & $\begin{array}{l}\text { LIMITED } \\
\text { REACTION } \\
\text { OR UNEQUAL } \\
\end{array}$ & SPARED & SMALLER & OVAL \\
\hline TRAUMA N=364 * & 59 & 72 & 19 & 9 & 2 & 3 \\
\hline $\begin{array}{ll}\text { TUMOR } & \mathrm{N}=158\end{array}$ & 39 & 57 & 34 & 9 & 4 & 5 \\
\hline $\begin{array}{l}\text { DIABETES } \\
\mathrm{N}=141\end{array}$ & 10 & 27 & 26 & 47 & 7 & 1 \\
\hline $\begin{array}{l}\text { ANEURYSM } \\
\mathrm{N}=143\end{array}$ & 61 & 77 & 21 & 2 & 3 & 2 \\
\hline SURGERY N=124 & 46 & 59 & 35 & 6 & 2 & 2 \\
\hline $\begin{array}{ll}\text { STROKE } & \mathbf{N}=110\end{array}$ & 43 & 59 & 27 & 14 & 2 & 5 \\
\hline $\begin{array}{l}\text { INFECTION } \\
\mathbf{N}=65\end{array}$ & 48 & 68 & 23 & 9 & 3 & 8 \\
\hline $\begin{array}{l}\text { G-B SYNDROME } \\
\mathbf{N = 3 4}\end{array}$ & 24 & 38 & 27 & 35 & $\mathbf{0}$ & 6 \\
\hline $\begin{array}{l}\text { FISHER } \\
\text { SYNDROME } \\
\mathbf{N}=\mathbf{2 4} \\
\end{array}$ & 38 & 50 & 25 & 25 & $\mathbf{0}$ & 17 \\
\hline ICS $\quad \mathrm{N}=46$ & 13 & 26 & 52 & 22 & 15 & $\mathbf{0}$ \\
\hline $\begin{array}{ll}\text { BENIGN } & \mathrm{N}=\mathbf{2 5} \\
\end{array}$ & $\mathbf{0}$ & 8 & 44 & 48 & 4 & $\mathbf{0}$ \\
\hline $\begin{array}{ll}\text { OTHER } & N=60\end{array}$ & 40 & 58 & 29 & 13 & 3 & 10 \\
\hline UNKNOWN N=34 & 3 & 15 & 38 & 47 & 3 & 0 \\
\hline TOTAL $\quad \mathrm{N}=1333$ & 42 & 57 & 28 & 15 & 3 & 4 \\
\hline $\begin{array}{l}\text { [HERNIATION } \\
\mathbf{N}=184 \\
\end{array}$ & 42 & 59 & 32 & 9 & 4 & 4 \\
\hline $\begin{array}{l}\text { [RECURRENT } \\
\mathrm{N}=\mathbf{8 8}\end{array}$ & 12 & 25 & 42 & 33 & 5 & $\mathbf{0}$ \\
\hline \multicolumn{7}{|l|}{ LOCATION } \\
\hline $\begin{array}{l}\text { CAVERNOUS } \\
\text { SINUS } \quad \mathrm{N}=295 \\
\end{array}$ & 46 & 59 & 30 & 11 & 2 & 5 \\
\hline $\begin{array}{l}\text { SUBARACHNOID } \\
\text { SPACE N=436 }\end{array}$ & 46 & 63 & 30 & 7 & 3 & 3 \\
\hline $\begin{array}{l}\text { BRAINSTEM } \\
\mathbf{N}=190\end{array}$ & 48 & 66 & 22 & 12 & 3 & 5 \\
\hline NERVES $N=164$ & 13 & 30 & 34 & 36 & 5 & 2 \\
\hline $\begin{array}{l}\text { UNKNOWN } \\
\mathbf{N}=\mathbf{2 4 8}\end{array}$ & 43 & 56 & 23 & 21 & 2 & 3 \\
\hline
\end{tabular}

$* \mathrm{~N}=$ number of cases with pupils unobscured by prior surgery or iatogenic dilatation

$53 \%$ of diabetic TNPs and in $59 \%$ of these, impairment was bilateral. Although only a few pupils were pharmacologically tested--with positive results, others displayed light-near dissociation, and autonomic neuropathy was a likely concomitant in many patients. A fixed pupil opposite a normal pupil was rare with diabetic TNPs (3\%), common with TNPs due to pcom aneurysms $(61 \%)$, and intermediate with TNPs caused by tumors $(29 \%)$. Complete pupillary sparing was most common with benign cases (48\%), diabetes (47\%), unknown causes (47\%) and the G-B (35\%) and F (25\%) syndromes, and least common with aneurysms (2\%), surgery $(6 \%)$, tumor $(9 \%)$, infection (9\%) and tentorial herniation (9\%) (Table 5).

A unique pupillary phenomenon occurred in a 26-year-old man with a traumatic complete TNP in whom the affected, lightfixed pupil rhythmically expanded and contracted once a second, unaccompanied by movement of the globe or the opposite normal pupil ${ }^{13}$.

Among unilateral cases, ptosis was complete in $54 \%$, severe in $8 \%$, moderate in $17 \%$, mild in $17 \%$, normal in $2 \%$, and unknown in $2 \%$. Overall, elevation (absent in $61 \%$ of unilateral cases and $66 \%$ of all TNPs) was slightly more affected than adduction (absent in 55\% and 59\%) or depression (absent in 52\% and $57 \%$ ), but the differences were modest and of no differential value.
Trauma, the cause of $26 \%$ of all TNPs, was the most common etiology by far, with vehicle-related injuries accounting for onehalf of the cases $(36 \%$ automobile, $11 \%$ pedestrian, and $3 \%$ bicycle) (Table 6). Despite presenting a small target, the TN was directly injured by penetrating trauma in 33 cases including one remarkable patient with an MRI-documented track of a sharpened screwdriver driven into the skull, through the cerebrum, to damage the $\mathrm{TN}$ fascicles in the cerebral peduncle ${ }^{14}$ (Table 6). Trauma was documented in $69 \%$ of cases of TNP caused by transtentorial herniation and subdural hematoma was the proximate cause of $67 \%$ of all tentorial herniations.

Tumors causing TNP were more often malignant (100 cases) than benign (71 cases) and nearly two-thirds involved the TN in the cavernous sinus (Tables 1,7). Common tumors included pituitary adenomas (24\%, more than half apoplectic), solid tumor metastases $(21 \%)$, and lymphomas (16\%--more than onethird associated with acquired immune deficiency syndrome) (Tables 1, 7). Surgery accounted for $10 \%$ of TNPs, with 87 aneurysm cases (30 basilar) easily outnumbering the 44 tumor surgeries (headed by 21 meningiomas and 12 pituitary adenomas) (Table 8).

Diabetes was present in 234 cases (17\% of all patients), but diabetic nerve ischemia was the cause of TNP in only 156 (two- 
Table 6: Sources of trauma causing third nerve palsy

\begin{tabular}{l|l|l|l}
\hline & $\begin{array}{l}\text { Total } \\
\# \text { cases }\end{array}$ & $\begin{array}{l}\text { Direct } \\
\text { trauma }\end{array}$ & $\begin{array}{l}\text { Secondary } \\
\text { Herniation }\end{array}$ \\
\hline AUTOMOBILE & 134 & 111 & 23 \\
\hline FALL & 60 & 20 & 40 \\
\hline PEDESTRIAN & 39 & 33 & 6 \\
\hline GUNSHOT WOUND & 33 & 28 & 5 \\
\hline BEATING & 29 & 20 & 9 \\
\hline BICYCLE & 30 & 10 & 20 \\
\hline STABBING & 10 & 5 & 5 \\
\hline HORSE & 5 & 3 & 2 \\
\hline OTHER* & 5 & 4 & 1 \\
\hline UNKNOWN & 4 & 3 & 1 \\
\hline TOTAL & 369 & 242 & 127 \\
\hline
\end{tabular}

*Soccer heading, car falling from jack, moped and tractor accidents

thirds of all diabetics and $11 \%$ of all TNPs). In the remaining 78 diabetics, the etiology of TNP was potentially related to diabetes in about half (stroke 24, infection 16). In five diabetics, pcom aneurysms were the cause of TNP. Pain was a presenting symptom in $69 \%$ and eye movements were completely affected in $51 \%$. Pupillary abnormalities $(53 \%, 31 \%$ bilateral) were common but anisocoria greater than $2 \mathrm{~mm}$ was seen in only $3 \%$. Despite extensive use of MRI, only a single case of an apparent (partial) diabetic TNP proved to be due to midbrain infarction ${ }^{15}$.

The 145 TNPs caused by aneurysms included $20 \%$ of isolated TNPs but just $5 \%$ of cases with other neurological signs. Only $6 \%$ (four with cavernous and three with supraclinoid carotid aneurysms) of the 120 patients able to give a history had no pain. The supraclinoid carotid artery was the site of 124 aneurysms, with 117 being true pcom aneurysms (Table 9). Middle-aged patients harbored most aneurysms, but three patients under the age 20 (the youngest, with coarctation, was 11) and two over 75 had pcom aneurysms. Of 78 patients with pcom aneurysms who had complete involvement of eye movements, the pupil was fixed in 66, minimally reactive in nine, and had limited reaction in the remaining three. The pupils were spared in only a single patient (with partial eye movement limitation).

Six of nine cavernous carotid aneurysms had additional cranial neuropathies. The seven TNPs caused by distal basilar aneurysms were overshadowed by 30 TNPs which followed basilar aneurysm surgery. In two cases, the onset of TNP coincided with subarachnoid hemorrhage from an aneurysm remote from the TN (anterior cerebral and a peripheral convexity mycotic aneurysm). No cause of bleeding could be determined in seven cases of subarachnoid hemorrhage.
Table 7: Tumors causing third nerve palsy

\begin{tabular}{|c|c|c|c|}
\hline \multirow[t]{2}{*}{ Tumor Type } & \multicolumn{3}{|c|}{ \# Patients } \\
\hline & PRESENT STUDY & MAYO $^{1-4}$ & WILLS $^{5}$ \\
\hline PITUITARY ADENOMA & 41 (22 apoplectic) & 70 & \\
\hline $\begin{array}{l}\text { METASTASES (SOLID } \\
\text { TUMOR) }\end{array}$ & 36 & 108 & 4 \\
\hline $\begin{array}{l}\text { LYMPHOMA } \\
\end{array}$ & 23 (8 AIDS) & & \\
\hline MENINGIOMA & 16 & 60 & 1 \\
\hline $\begin{array}{l}\text { NASOPHARYNGEAL } \\
\text { CARCINOMA } \\
\end{array}$ & 14 & 12 & \\
\hline GLIOMA & 12 & 7 & \\
\hline LEUKEMIA & 6 & & \\
\hline SARCOMA & 4 & & \\
\hline SCHWANNOMA* & 4 & & \\
\hline CRANIOPHARYNGIOMA & 4 & & \\
\hline $\begin{array}{l}\text { CHORDOMA/ } \\
\text { CHONDROMA }\end{array}$ & 4 & 10 & \\
\hline OTHER & $9^{\#}$ & 43 & \\
\hline TOTAL & 173 & 310 & 5 \\
\hline
\end{tabular}

*2 of 8 th nerve and 2 of 5 th nerve origin; \#2 plasmacytoma, 2 unknown. 1 each germinoma, primitive neuroectodermal tumor, oligodendroglioma, pinealoma, epidermoid

Table 8: Operations causing third nerve palsy

ANEURYSM 87

POST. COMMUNICATING ARTERY 36

BASILAR ARTERY

30

OTHER LOCATIONS

21

TUMOR

44

MENINGIOMA

21

PITUITARY ADENOMA

12

CHORDOMA

4

CRANIOPHARYNGIOMA

3

SCHWANNOMA

2

EPIDERMOID

2

ARTERIOVENOUS MALFORMATION 3

CAROTID-CAVERNOUS FISTULA 2

OTHERS*

4

TOTAL

140

*1 each cysticercosis, ethmoiditis, abscess drain insertion, cavernous angioma 
Table 9: Description and pupillary signs of TNPs due to aneurysms (number of cases)

\begin{tabular}{|c|c|c|c|c|c|c|c|c|c|c|}
\hline \multicolumn{4}{|c|}{ Description } & \multicolumn{7}{|c|}{ Pupil reactions } \\
\hline LOCATION & ALL & GIANT & MYCOTIC & FIXED & MINIMAL & LIMITED & $\begin{array}{l}\text { NORMAL/ } \\
\text { DILATED }\end{array}$ & NORMAL & OBSCURED* & NORMAL \\
\hline $\begin{array}{l}\text { POST } \\
\text { COMMUNICATING } \\
\text { A. }\end{array}$ & 117 & 2 & $\overline{0}$ & 76 & 13 & 19 & 6 & $1+1 * *$ & 1 & 1 \\
\hline $\begin{array}{l}\text { CAVERNOUS } \\
\text { CAROTID A. }\end{array}$ & 9 & 2 & $\mathbf{0}$ & 5 & 2 & 2 & $\mathbf{0}$ & $\mathbf{0}$ & & $\mathbf{0}$ \\
\hline OTHER CAROTID A. & 7 & 4 & $\mathbf{0}$ & 3 & 2 & 1 & $\mathbf{0}$ & $0+1 * *$ & & 1 \\
\hline BASILAR A. & 7 & 1 & 1 & 5 & 1 & $\mathbf{0}$ & 1 & $\mathbf{0}$ & & $\mathbf{0}$ \\
\hline $\begin{array}{l}\text { POSTERIOR } \\
\text { CEREBRAL A. }\end{array}$ & 1 & $\mathbf{0}$ & 1 & 1 & $\mathbf{0}$ & $\mathbf{0}$ & $\mathbf{0}$ & $\mathbf{0}$ & & \\
\hline $\begin{array}{l}\text { ANTERIOR } \\
\text { CEREBRAL A. }\end{array}$ & 1 & $\mathbf{0}$ & $\mathbf{0}$ & $\mathbf{0}$ & $\mathbf{0}$ & $\mathbf{0}$ & $\mathbf{0}$ & 1 & & 1 \\
\hline PERIPHERAL A. & 1 & $\mathbf{0}$ & 1 & 1 & $\mathbf{0}$ & $\mathbf{0}$ & $\mathbf{0}$ & $\mathbf{0}$ & & $\mathbf{0}$ \\
\hline UNKNOWN & 2 & o & $\mathbf{0}$ & 1 & $\mathbf{0}$ & $\mathbf{0}$ & $\mathbf{0}$ & $\mathbf{0}$ & 1 & $\mathbf{0}$ \\
\hline TOTAL & 145 & 9 & 3 & 92 & 18 & 22 & 7 & $2+2 * *$ & 2 & 3 \\
\hline
\end{tabular}

*iatrogenically-dilated pupils; $* *$ superior division palsies

Primary midbrain strokes were responsible for $7 \%$ of all TNPs and $18 \%$ of bilateral TNPs. Of the 96 cases, $82 \%$ were infarcts, five associated with vasculitis (Table 10). Midbrain hemorrhage in 19 cases (13 associated with vascular malformation), originated in the midbrain in ten, dissected from the thalamus in six and from the pons in three. In only two midbrain strokes were TNPs the sole neurological sign ${ }^{16}$.

Table 10: Vascular causes of third nerve palsy

\begin{tabular}{l|l}
\hline CAUSE & \# CASES \\
\hline ANEURYSM & 145 \\
\hline MIDBRAIN STROKE & 96 \\
\hline Infarct* & 77 \\
\hline Hemorrhage** & 19 \\
\hline $\begin{array}{l}\text { VASCULAR CAUSES OF HERNIATION } \\
\text { (no history of trauma) }\end{array}$ & 47 \\
\hline Subdural Hematoma & 29 \\
\hline Cerebral Hemorrhage & 14 \\
\hline Cerebral Infarct & 4 \\
\hline MISCELLANEOUS VASCULAR CAUSES & 16 \\
\hline Subarachnoid Hemorrhage, Unknown Cause & 7 \\
\hline Carotid-Cavernous Fistula $* * *$ & 2 \\
\hline Microvascular Ischemia & 7 \\
\hline TOTAL & 304 \\
\hline
\end{tabular}

*Includes 5 cases of vasculitis; **Includes 10 arteriovenous malformations, 3 cavernous angioma, 1 pregnancy induced hypertension, 1 idiopathic thrombocytopenic purpura; ***additional cases tallied under surgery (2) and trauma (1)
Tentorial herniation without known trauma resulted in 47 TNPs. Overall, herniation caused 186 TNPs in association with 95 subdural hematomas, 44 epidural hematomas, 33 parenchymal hemorrhages, 5 tumors, 4 infarcts, 2 cerebral abscesses, 1 epidural abscess, and 2 unknown. Bilateral subdural hematomas were the result rather than the cause of herniation in a confusing patient with headache and a TNP which switched sides after several days. Magnetic resonance imaging showed signs of spontaneous intracranial hypotension and he promptly responded to an intrathecal blood patch.

In 65 cases of infection, the meninges were principally involved in nearly half $(48 \%)$, the brainstem in $23 \%$, and cavernous sinus in $17 \%$ (Table 11). Nearly one-fourth of all cases were due to bacterial meningitis, but a wide range of infections were represented. Acquired immune deficiency syndrome was present in 19 patients, of whom 8 had lymphoma (meningeal in 6), 6 had toxoplasmosis, and 5 had cryptococcal meningitis. Cysticercosis is the most common nervous system infection on our neurology service but was associated with TNPs in only six cases: Three resulted from midbrain cysts, one was due to cysticercal meningitis, and two were indirect: one a secondary vasculitic infarction and the other resulted from surgical removal of a cysticercal cyst. Other diseases of local importance included wound botulism (four cases) and coccidiomycosis (one case). Syphilis and tuberculosis continue to be occasional causes of TNP in our municipal hospital.

Potentially dangerous delay in diagnosis occurred with two cases of meningitis. Both presented with partial TNPs several weeks after the onset of headache. After lumbar puncture showed cerebrospinal fluid pleocytosis with a few red cells but no xanthochromia, diagnoses of subacute infectious meningitis were made. Progression of TNPs led to the discovery of causative pcom aneurysms. In retrospect, cerebrospinal fluid changes un-doubtedly reflected a late meningeal reaction to subarachnoid hemorrhage ${ }^{17}$.

The G-B and Fisher syndromes (62 patients) occasionally present with isolated TNPs, but a more diffuse ophthalmoparesis is usual: $84 \%$ had bilateral TNPs and $32 \%$ had complete bilateral 
Table 11: Infectious causes of third nerve palsy (number of cases)

\begin{tabular}{|c|c|c|c|c|c|}
\hline \multirow[t]{2}{*}{ CAUSE } & \multicolumn{3}{|c|}{ LOCATION } & \multirow[b]{2}{*}{$\begin{array}{l}\text { CAVERNOUS } \\
\text { SINUS }\end{array}$} & \multirow[b]{2}{*}{$\begin{array}{l}\text { UNKNOWN/ } \\
\text { DIFFUSE }\end{array}$} \\
\hline & TOTAL & MENINGITIS & BRAINSTEM & & \\
\hline BACTERIA & 19 & 15 (2 solitary) & 2 (solitary) & 2 & \\
\hline MUCORMYCOSIS & 7 & & & 7 & \\
\hline BOTULISM (wound 4) & 7 & & & & 7 \\
\hline TOXOPLASMOSIS & 6 & & 6 (6 AIDS) & & \\
\hline CRYPTOCOCCUS & 6 & 6 (5 AIDS: 3 solitary) & & & \\
\hline TUBERCULOSIS & 4 & 2 & 1 & & 1 \\
\hline SYPHILIS & 4 & 2 & 2 (1 solitary) & & \\
\hline CYSTICERCOSIS & 4 & 1 & 3 & & \\
\hline HERPES ZOSTER & 2 & 1 & & 1 & \\
\hline COCCIDIOMYCOSIS & 1 & 1 & & & \\
\hline ASPERGILLIS & 1 & & & 1 & \\
\hline CANDIDA & 1 & 1 (solitary) & & & \\
\hline UNKNOWN & 3 & 2 & 1 & & \\
\hline TOTAL & 65 & 31 & 15 & 11 & 8 \\
\hline
\end{tabular}

ocular paralysis. By contrast, idiopathic cavernous sinusitis (Tolosa-Hunt syndrome) (ICS) (49 cases), presented with an isolated TNP in $20 \%$ and complete unilateral ocular paralysis in just $4 \%$. Indeed, damage to the sixth (12 cases) and fourth ( 7 cases) nerves was much less common with ICS than impairment of the second ( 37 cases) and fifth (26 cases) nerves. Benign selflimited cases, often recurrent, compose $2 \%$ of this series.

Other causes/associations (63 cases) include subdural hematoma causing tentorial herniation without evidence of trauma 29, subarachnoid hemorrhage of unknown cause 7 , nondiabetic microvascular ischemia 7 , congenital 5 , spontaneous carotid cavernous fistula 2, ophthalmoplegic migraine syndrome 2 , acute hydrocephalus of unknown origin 2, and one each spontaneous intracranial hypotension, lymphomatoid granulomatosis, histiocytosis, acute demyelination, Leigh's disease, Chronic Inflammatory Demyelinating Polyneuropathy, severe basilar artery ectasia, benign intracranial hypertension syndrome, and an undiagnosed neuro-degeneration with parkinsonian features. In 37 cases the cause was unknown.

\section{DISCUSSION}

\section{History}

Whereas Galen (130-201) believed that the oculomotor nerve (the 2nd of his seven cranial nerves) supplied all of the extraocular muscles, Willis (1621-1675) established the oculomotor as the third cranial nerve (of his eight) and connected the $3 \mathrm{rd}$, 4th, and 6th nerves with the appropriate muscles ${ }^{18}$.

In 1888, Gowers was aware that tumors, meningitis and aneurysms caused TNP and considered "rheumatic neuritis" due to cold drafts as an unproven but "highly probable"cause ${ }^{19}$. Less than 20 years later, a dozen cases of diabetic ocular palsy had been recognized, myasthenia had emerged from the catch-all diagnosis of "nuclear ophthalmoplegia," and belief in rheumatic

Table 12: Comparison of third nerve palsy series

\begin{tabular}{|c|c|c|c|c|c|c|c|c|}
\hline \multirow[b]{2}{*}{ CAUSE } & \multicolumn{2}{|c|}{ PRESENT STUDY } & \multicolumn{2}{|c|}{ MAYO CLINIC $^{1-4}$} & \multirow{2}{*}{\begin{tabular}{|c|} 
BERLIT $^{11}$ \\
$\begin{array}{c}\text { ISOLATED } \\
\mathbf{N}=172\end{array}$ \\
\end{tabular}} & \multirow{2}{*}{$\begin{array}{l}\text { GREEN, }^{6} \\
\begin{array}{l}\text { TOTAL } \\
\text { N=130 }\end{array}\end{array}$} & \multirow{2}{*}{$\begin{array}{l}\text { LAERE }^{8} \\
\begin{array}{l}\text { TOTAL } \\
\text { N=109 }\end{array}\end{array}$} & \multirow{2}{*}{$\begin{array}{l}\text { Combined } \\
\text { Smaller } \\
\text { Series } \\
5,7,9,10\end{array}$} \\
\hline & $\begin{array}{l}\text { TOTAL } \\
\mathbf{N}=1400\end{array}$ & $\begin{array}{c}\text { ISOLATED } \\
\mathbf{N}=\mathbf{5 0 0}\end{array}$ & $\begin{array}{l}\text { TOTAL } \\
\mathbf{N}=1491\end{array}$ & $\underset{\mathbf{N}=1136}{\text { ISOLATED }}$ & & & & \\
\hline TRAUMA & $26 \%$ & $21 \%$ & $15 \%$ & 15 & $6 \%$ & $11 \%$ & $11 \%$ & $8 \%$ \\
\hline TUMOR & 12 & 6 & 14 & 16 & 7 & 4 & 4 & 19 \\
\hline DIABETES & 11 & 26 & $-{ }^{* *}$ & --** & 42 & 19 & 1 & 25 \\
\hline $\begin{array}{l}\text { ISCHEMIC } \\
\text { (NONDIABETIC) }\end{array}$ & $<1$ & $<2$ & $13^{*}$ & $17 *$ & 7 & 15 & - & 9 \\
\hline ANEURYSM & 10 & 21 & 3 & 3 & 9 & 29 & 17 & 16 \\
\hline SURGERY & 10 & 8 & -- & --- & & $\mathbf{0}$ & 2 & $\mathbf{0}$ \\
\hline STROKES + & 8 & 1 & 17 & 12 & & --- & 33 & 3 \\
\hline INFECTION & 5 & 2 & -- & - & 8 & 9 & - & - \\
\hline G-B syndrome & 3 & $\mathbf{0}$ & --- & - & & $\mathbf{0}$ & -- & -- \\
\hline FISHER synd & 2 & 0 & --- & - & & 0 & - & -- \\
\hline ICS & 3 & 2 & --- & - & & 0 & - & -- \\
\hline BENIGN & 2 & 4 & -- & - & & - & 6 & \\
\hline OTHER & 4 & 2 & 16 & 14 & 11 & 4 & 6 & 14 \\
\hline UNKNOWN & 3 & 5 & 21 & 24 & 10 & 8 & 28 & 9 \\
\hline
\end{tabular}

*diabetic and nondiabetic microvascular ischemic cases grouped together 
palsies persisted ${ }^{20}$. In the century since, insulin, antibiotics, cerebral angiography, and the automobile have affected the rank order of TNP causes and rheumatic palsy slowly became extinct.

\section{Analysis of cases}

The present study reflects a municipal hospital's heavy burden of poverty, trauma, and neglected disease. A few cases of cysticercosis are the principal reminder of the large immigrant population. Bilateral $\mathrm{TNPs}^{21}$, multiple cranial neuropathies ${ }^{22}$, and accompanying neurological signs are common among our inpatients, as are causes seldom seen in outpatient settings such as severe trauma, midbrain strokes, and the G-B syndrome.

Divisional palsies of the TN have long been recognized ${ }^{23}$, and two cases caused by aneurysms were included in an early TNP series $^{6}$. Once thought to strictly parallel TN anatomy and localize in or near the orbit, division palsies have repeatedly been demonstrated with lesions in the brainstem and subarachnoid space. Myasthenia often mimics superior division palsies as, on occasion, do lesions of the orbital roof ${ }^{24}$.

Recurrent cranial neuropathies usually signify benign disease, but 18 of the 93 patients in this study with recurrent neuropathies -4 with aneurysms-- had ominous conditions. One in seven patients had a prior neuropathy unrelated to the present condition; in particular, previous seventh nerve palsy does not guarantee benignity.

Smaller pupils--in $3 \%$ of our patients--accompany TNP occasionally in other series ${ }^{5}$. Horners syndrome and diabetic autonomic neuropathy could explain about one-quarter of our cases. Physiological anisocoria $(\geq 0.5 \mathrm{~mm})$, seen in $9 \%$ of normal pupils on single observations ${ }^{25}$, could account for a few more cases, but at least nine cases had no ready explanation. Pupils in third nerve palsy due to cavernous sinus lesions are said to be relatively smaller because of co-existing sympathetic deficits but pharmacological testing has not supported that thesis ${ }^{26}$. In the present study, miosis was relatively uncommon with lesions in the cavernous sinus overall, but occurred in $15 \%$ of our patients with ICS (Table 5).

The $1 \%$ incidence of pupillary sparing in our cases of pcom aneurysms is similar to the $2-3 \%$ in previous studies ${ }^{1,2,5}$ but lower than some studies utilizing neurosurgical chart review, a process which may overlook some patients with subtle pupillary abnormalities $^{27}$.

Among the more mysterious of TNPs are those-like two in our series--which coincide with aneurysm ruptures remote from the TN. An early TNP study included a ruptured middle cerebral artery aneurysm ${ }^{5}$, and a number of case reports of remote aneurysms at different sites have been published. The obvious explanation in such cases, as in our seven cases without a source of subarachnoid hemorrhage, would be that the bleeding aneurysm was destroyed during rupture and the remote aneurysm was incidental. However, evidence in our cases and others, from imaging and surgery, is against that premise. Other explanations are highly speculative, but a few patients (like our mycotic aneurysm case)--could possibly represent a "double hit" in which a TN weakened by meningitis develops a manifest palsy in the face of sudden severe increased intracranial pressure $^{28}$.

Despite our hospital's low admission threshold, microvascular ischemia is under-represented in the present study and it's likely that our inpatient diabetics are sicker than the usual ischemic TNP patient. Our 53\% incidence of pupillary involvement with diabetic TNP is considerably higher than the usual $10-40 \%$ range and more than half of our cases with affected pupils had bilateral involvement, probably reflecting associated diabetic autonomic neuropathy. An additional possibility, perhaps unique to a municipal hospital population, is the high frequency of repeated--and often forgotten-eye trauma, which could provide a cause for an occasional unexplained pupillary abnormality ${ }^{29}$.

Idiopathic cavernous sinusitis is mentioned only occasionally in TNP series. The cavernous sinus was relatively blind to radiological investigation before modern imaging and it's likely that some cases of "sinusitis" or "presumed parasellar aneurysms" actually had ICS. Although it remains a diagnosis of exclusion which can be confused with lymphoma and other tumors, and atypical presentations led to surgical exploration in two of our cases, MRI diagnosis of ICS has proven surprisingly accurate $^{30}$.

While antibiotics have demoted infection from the principal etiologies of TNPs, it continues to be a frequently obscure and singularly treatable cause. Among our patients, cysticercosis reflected immigration from Mexico and Central America, coccidiomycosis resulted from residency in the Southwestern deserts, wound botulism was caused by "skin-popping" drugs under unsterile conditions, and syphilis and tuberculosis reflected our patients' culture of poverty.

Multiple sclerosis (MS) was mistakenly considered a common cause of TNP before internuclear ophthalmoplegia became recognized. While it's an occasional cause of sixth nerve palsy, it's curiously rare as a cause of TNP. Only one of our cases had MS (vs acute demyelinating encephalomyelitis) and there is a dichotomy in the reported incidence with many TNP studies having a single case of MS or none at all $1,5,6,9,10$ and others reporting a $2-3 \%$ incidence ${ }^{2,3,7,11}$.

\section{Other studies}

The hallmark Mayo Clinic studies of ocular motor palsies, encompassing a 40 year period through 1988, included 1491 patients with $\mathrm{TNP}^{1-4}$ (Table 12). Most patients had isolated TNPs ( $76 \%$ vs $36 \%$ in the present study) and many remained undiagnosed (21\% vs $3 \%)$. Trauma, although less common (15\% vs $26 \%$ ), was still a major cause. Aneurysms (14\% vs $10 \%)$ and tumors $(17 \%$ vs $12 \%)$ were somewhat more common at Mayo but infections ( $3 \%$ vs $5 \%$ ) less so.

Other reports of TNP prior to the widespread use of computed scanning include experience at the Massachusetts Eye and Ear Infirmary $(1960)^{5}$ (59 patients:19\% aneurysms and $34 \%$ diabetic TNP), the Wills Eye Hospital neurology clinic study $(1964)^{6}$ (130 patients: $29 \%$ aneurysms and $19 \%$ diabetes), a series from Washington University $(1965)^{7}$ (53 patients: ischemia $28 \%$, aneurysm $19 \%$ and tumor $19 \%$ ), and a study from a Belgium neurosurgery clinic $(1971)^{8}(109$ patients: aneurysms $36 \%$, tumors $16 \%$, and unknown $27 \%$ ) (Table 11).

Later studies utilizing CT scans included a report from a university neurology department $(1985)^{9}$ (61 patients with isolated TNPs: ischemia 38\%, tumor $21 \%$, trauma 15\%), a university neuro-ophthalmology series featuring a cliniconeuroradiologic approach $(1987))^{10}(63$ patients: miscellaneous $19 \%$, 
ischemic $16 \%$, tumor $16 \%$, and undiagnosed $2 \%$ ), and a review of ocular motor palsy among university hospital inpatients $(1990)^{11}$ (218 patients altogether; of 172 with isolated TNPs: $42 \%$ diabetes, $10 \%$ unknown, $9 \%$ aneurysm).

The present study is the first to utilize MRI frequently. Early MRI technique was not sufficiently sensitive to detect all aneurysms causing $\mathrm{TNPs}^{31}$. Now, however, the best modern magnetic resonance angiography (MRA) and computarized tomographic angiography equipment, in experienced hands, can detect all aneurysms of sufficient size to cause TNP, with minimal complications and at a nearly-reasonable cost. In evaluating TNPs of uncertain cause, both diagnostic catheter angiography and watchful waiting should soon give way to prompt MRI/MRA screening.

\section{ACKNOWLEDGEMENT}

The author thanks Frances C. Keane, RN, MPH, who helped with data retrieval and organization.

\section{REFERENCES}

1. Rucker CW. Paralysis of the third, fourth and sixth cranial nerves. Am J Ophthalmol. 1958;46:787-94.

2. Rucker CW. The causes of paralysis of the third, fourth and sixth cranial nerves. Am J Ophthalmol. 1966;61:1293-8.

3. Rush JA, Younge BR. Paralysis of cranial nerves III, IV, and VI: cause and prognosis in 1000 cases. Arch Ophthalmol. 1981;99: 76-9.

4. Richards BW, Jones FR Jr, Younge BR. Causes and prognosis in 4278 cases of paralysis of the oculomotor, trochlear, and abducens cranial nerves. Am J Ophthalmol. 1992;113:489-96.

5. Goldstein JE, Cogan DG. Diabetic ophthalmoplegia with special reference to the pupil. Arch Ophthalmol. 1960;64:592-600.

6. Green WR, Hackett ER, Schlezinger NS. Neuro-ophthalmologic evaluation of oculomotor nerve paralysis. Arch Ophthalmol. 1964;72:154-67.

7. Cheek CW, Simon KA, Gay AJ. Acquired cranial nerve lesions affecting the ocular system. Am J Ophthalmol. 1965;59:13-7.

8. van Laere E. La paralysie non traumatique du nerf oculomoteur commun. A propos de 109 observations. Acta Neurol Belg. 1974; 74:182-92.

9. Teuscher AU, Meienberg O. Ischaemic oculomotor nerve palsy; clinical features and vascular risk factors in 23 patients. J Neurol. $1985 ; 232: 144-9$.

10. Kwan ESK, Laucella M, Hedges TR jr, et al. A cliniconeuroradiologic approach to third cranial nerve palsies. AJNR Am J Neuroradiol. 1987;8: 459-68.

11. Berlit P. Isolated and combined pareses of cranial nerves III, IV, and VI. A retrospective study of 412 patients. J Neurol Sci. 1991; 103:10-5.

12. Wallace SP, Mendez-Luck C, Castafieda X. Heading south: why Mexican immigrants in California seek health services in Mexico. Med Care. 2009:47:662-9.

13. Keane JR. Rhythmic pupillary oscillations accompanying a complete third nerve palsy. J Clin Neuro-ophthalmol. 1989;9: 169-70.

14. Keane JR. Third nerve palsy due to penetrating trauma. Neurology. 1993:43:1523-7.

15. Keane JR, Ahmadi J. Most diabetic third nerve palsies are peripheral. Neurology. 1998;51;1510.

16. Keane JR. Isolated brain stem third nerve palsy. Arch Neurol. 1988; 45:813-4.

17. Keane JR. Aneurysmal third nerve palsy presenting with pleocytosis. Neurology. 1996:46:1176.

18. Rucker CW. History of the numbering of the cranial nerves. Mayo Clin Proc.1966;41:453-61.

19. Gowers W. Diseases of the nervous system. Philadelphia: JB Lippincott Co; 1888. p. 612-16.
20. Duane A. The extra-ocular muscles. In: Posey WM, Spiller WG, editors. The eye and the nervous system. Philadelphia: JB Lippincott Co; 1906. p. 222-41.

21. Keane JR. Bilateral involvement of a single cranial nerve. Analysis of 578 cases. Neurology. 2005;65:950-2.

22. Keane JR. Multiple cranial nerve palsies: analysis of 979 cases. Arch Neurol. 2005;62:1714-17.

23. Williams HW. The diagnosis and treatment of diseases of the eye. Boston: Houghton, Mifflin \& Co; 1881. p. 310.

24. Keane JR. Ptosis and levator palsy caused by orbital roof fractures: three cases with subfrontal epidural hematomas. J Clin Neuroophthalmol. 1993;13:225-8.

25. Lam BL, Thompson HS, Corbett JJ. The prevalence of simple anisocoria. Am J Ophthalmol. 187;104:69-73.

26. Trobe JD. Glaser JS, Post JD. Meningiomas and aneurysms of the cavernous sinus: neuro-ophthalmologic features. Arch Ophthalmol. 1978;96:457-67.

27. Keane JR. Aneurysms and third nerve palsies. Ann Neurol. 1983; $14 ; 696-7$.

28. Keane JR. Intermittent third nerve palsy with cryptococcal meningitis. J Clin Neuroophthalmol. 1993;13:124-6.

29. Keane JR. Functional diseases affecting the cranial nerves. In: J Noseworthy, editor. Neurological therapeutics: principles and practice. 2nd ed. London: Martin Dunitz; 2006. p. 2202.

30. Keane JR. Cavernous sinus syndrome: analysis of 151 cases. Arch Neurol. 1996;53:967-71.

31. Keane JR. Third nerve palsies and angiography. Arch Neurol. 1991; 48:470. 